\title{
SINTAKS MODEL PEMBELAJARAN MATEMATIKA COLLABORATIVE PROBLEM SOLVING PADA MATERI SISTEM PERSAMAAN LINEAR TIGA VARIABEL (SPLTV)
}

\author{
Mar'ah Rohmatul Ummah ${ }^{1}$, Abdul Halim Fathani \\ 1,2 Pendidikan Matematika, Fakultas Keguruan dan Ilmu Pendidikan, Universitas Islam Malang \\ rohmatulmaret@gmail.com ${ }^{1}, \underline{\text { fathani@unisma.ac.id }}^{2}$
}

\begin{abstract}
Collaborative problem solving mathematics learning model aim for add new variation releated mathematics learning model which has been done by teachers. This learning model is new learning model which comes from a combination collaborative learning model and problem solving learning method. Based on the collaborative learning model supported by cognitive theory, social constructivism theory, and motivation theory. While the problem solving learning method supported by theory that refers to Polya steps. In addition to theories that support this learning model, a learning model includes approach, strategy, method, technique, and learning tactics. Collaborative problem solving learning model includes the following: (1) student centered approach; (2) discovery learning strategy and deductive learning strategy; (3) problem solving learning method; (4) study group technique; and (5) task LKPD tactics. After the collaborative problem solving learning model is formed, then the next step is making learning model syntax. Syntax of collaborative problem solving learning model is: (1) engagement; (2) exploration; (3) transformation; (4) solution; (5) presentation; and (6) reflection.
\end{abstract}

Keywords: pore number, maccormack, stabilization of peat soil

\section{PENDAHULUAN}

Belajar dan pembelajaran merupakan hal yang saling terkait satu sama lain. Aktivitas belajar peserta didik berlangsung dalam suatu proses pembelajaran. Sebaliknya proses pembelajaran dapat berlangsung dengan baik apabila mendapat respon dari peserta didik. Oleh karena itu, belajar dan pembelajaran menjadi hal yang tidak terpisahkan dalam proses pembelajaran. The Guidance of Learning Activities W.H. Burton (dalam Siregar, 2014:4) menyatakan bahwa belajar merupakan proses perubahan tingkah laku pada diri individu karena adanya interaksi antara individu dengan individu dan individu dengan lingkungannya sehingga mereka lebih mampu berinteraksi dengan lingkungannya. Belajar dapat terjadi melalui pengalaman seseorang. Hal tersebut sesuai dengan Gagne (dalam Siregar, 2014:4) menjelaskan bahwa belajar merupakan suatu perubahan perilaku yang relatif menetap yang dihasilkan dari pengalaman masa lalu. Selain pengalaman, belajar juga terjadi melalui latihan yang didukung oleh Morgan (dalam Thobroni, 2013:18) menjelaskan bahwa belajar merupakan setiap perubahan yang relatif menetap dalam tingkah laku yang terjadi sebagai suatu hasil dari latihan atau pengalaman. Dengan demikian, belajar merupakan proses perubahan tingkah laku yang permanen dan diperoleh melalui latihan atau pengalaman.

Pembelajaran juga salah satu bagian penting dalam pendidikan. Keberhasilan proses pembelajaran dipengaruhi oleh beberapa faktor yaitu guru, peserta didik, prasarana dan lingkungan (Sanjaya dalam Abidin, 2016:79). Namun, hal yang sangat mempengaruhi proses pembelajaran adalah guru dan peserta didik. Ketika proses pembelajaran berlangsung, terjadi interaksi antara guru dengan peserta didik sehingga guru dapat mengetahui karakteristik dan potensi yang dimiliki peserta didik. Demikian sebaliknya, peserta didik dapat mengembangkan potensi yang dimiliki. Pembelajaran 
dapat dimanfaatkan untuk kebutuhan belajar dan peserta didik diposisikan sebagai subjek belajar yang memegang peran utama sehingga dalam proses pembelajaran peserta didik dituntut aktif untuk mempelajari bahan pelajaran. Peserta didik sebagai subjek belajar harus aktif mencari, menemukan, memecahkan, dan menyimpulkan suatu masalah. Hal tersebut sesuai dengan Siregar (2014:14) mengemukakan bahwa pembelajaran harus menghasilkan belajar pada peserta didik dan harus dilakukan suatu perencanaan yang sistematis, sedangkan pengajaran hanya salah satu penerapan strategi pembelajaran dengan tujuan utamanya menyampaikan informasi kepada peserta didik. Sehingga, pembelajaran dan pengajaran merupakan dua hal yang berbeda. Pembelajaran lebih bersifat student centered (berpusat pada peserta didik), sedangkan pengajaran bersifat teacher centered (berpusat pada guru).

Pembelajaran tidak terlepas dari model pembelajaran. Model pembelajaran merupakan suatu rancangan yang di dalamnya menggambarkan sebuah proses pembelajaran yang dapat dilaksanakan oleh guru dalam menstransfer pengetahuan maupun nilai-nilai kepada peserta didik (Suprihatiningrum, 2016:145). Model pembelajaran juga dapat membantu guru dalam mencapai tujuan pembelajaran dengan cara menyusun langkah-langkah pembelajaran yang sistematis. Hal ini sesuai dengan pendapat Trianto (2011:52) menjelaskan bahwa model pembelajaran merupakan kerangka konseptual yang menggambarkan prosedur sistematis dalam mengorganisasikan pengalaman belajar untuk mencapai tujuan belajar tertentu dan berfungsi sebagai pedoman bagi perancang pembelajaran dan para guru dalam merancang dan melaksanakan pembelajaran. Sedangkan, Joyce (2009:6) menyatakan bahwa model pembelajaran merupakan suatu rancangan pembelajaran yang digunakan sebagai pedoman pelaksanaan pembelajaran agar guru dapat berinteraksi dengan peserta didik. Dengan demikian, model pembelajaran merupakan suatu perencanaan yang menggambarkan sebuah proses pembelajaran daria awal sampai akhir yang digunakan sebagai pedoman guru dalam melaksanakan pembelajaran. Hal yang terpenting dalam suatu model pembelajaran yaitu sintaks/tahapan. Sintaks merupakan deskripsi implementasi model pembelajaran di lapangan yang sistematis. Setiap model pembelajaran, mempunyai sintaks berbeda-beda sesuai model pembelajaran yang digunakan oleh guru. Selain sintaks, model pembelajaran mempunyai komponen-komponen yaitu sistem sosial, prinsip reaksi, sistem pendukung, dampak instruksional, dan dampak pengiring (Joyce, 2009:104). Akan tetapi dalam hal ini yang dibahas tentang sintaks model pembelajaran, dikarenakan sintaks termasuk hal utama dalam model pembelajaran.

Dalam pelaksanaan pembelajaran matematika selama ini, kebanyakan guru masih menggunakan model pembelajaran konvensional. Sehingga peserta didik hanya menyerap informasi, menghafal, dan mencatat dari penjelasan materi yang dilakukan oleh guru. Hal ini peserta didik tidak dituntut memahami materi, mengungkapkan ide, dan memecahkan masalah matematika. Selain itu, guru masih menggunakan model pembelajaran kooperatif dalam proses pembelajaran matematika. Menurut Majid (2016:174) model pembelajaran kooperatif merupakan model pembelajaran yang mengutamakan kerja sama kelompok heterogen untuk mencapai tujuan pembelajaran. Model pembelajaran kooperatif merupakan model pembelajaran yang melibatkan peserta didik bekerjasama dalam kelompok untuk mencapai tujuan tertentu (Lee dalam Khoiriyah, 2016:15). Dalam hal ini, dikhawatirkan sebagian anggota kelompok (individu) tidak aktif dalam proses pembelajaran.

\section{PERSPEKTIF TEORI}

Salah satu solusi yang dapat dilakukan terkait hal tersebut yaitu dengan menggunakan model collaborative learning. Kata kolaborasi dalam bahasa Inggris yaitu "collaborate" atau "collaboration" berarti kerja sama (Husain, 2012:107). Berkolaborasi berarti bekerja bersama-sama dengan orang lain untuk mencapai tujuan tertentu. Dalam bekerja sama, setiap individu harus mempunyai kontribusi yang setara dalam melaksanakan 
suatu kegiatan. Hal ini sesuai dengan Barkley (2005:6) menyatakan bahwa model collaborative learning merupakan model pembelajaran yang melibatkan dua atau lebih peserta didik yang bekerja bersama-sama dan berbagi beban kerja secara setara sembari, secara perlahan, dan dapat mewujudkan hasil-hasil pembelajaran yang diinginkan. Menurut Brodie (dalam Damayanti, 2017:35) model collaborative learning sebagai proses komunikatif dapat memfasilitasi terjadinya penggabungan antara pengetahuanpengetahuan sebagai hasil interaksi antara dua atau lebih peserta didik. Sehingga, adanya interaksi tersebut dapat membangun pemahaman setiap individu dan kelompok. Dengan demikian, model collaborative learning merupakan model pembelajaran yang melibatkan dua atau lebih peserta didik yang memiliki kontribusi setara dalam bekerja sama untuk mencapai tujuan tertentu.

Menurut Piaget dan Vigotsky (dalam Sunismi, 2017:180) pembelajaran kolaboratif didukung oleh 3 teori yaitu teori kognitif, teori kontruktivisme sosial, dan teori motivasi. Teori kognitif berkaitan dengan terjadinya pertukaran konsep antar anggota kelompok pada pembelajaran kolaboratif sehingga dalam suatu kelompok akan terjadi proses transformasi ilmu pengetahuan pada setiap anggota. Teori konstruktivisme sosial berkaitan dengan interaksi sosial antar anggota yang akan membantu perkembangan individu dan meningkatkan sikap saling menghormati pendapat semua anggota kelompok. Sedangkan, teori motivasi berkaitan dengan teraplikasi dalam struktur pembelajaran kolaboratif karena pembelajaran tersebut akan memberikan lingkungan yang kondusif bagi peserta didik untuk belajar, menambah keberanian anggota kolompok untuk memberi pendapat dan menciptakan situasi saling membutuhkan bantuan pada seluruh anggota dalam kelompok.

Johnson dan Johnson (dalam Husain, 2012:14) menyatakan unsur-unsur pembelajaran kolaboratif yaitu saling ketergantungan positif, interaksi langsung antar peserta didik, pertanggungjawaban individu, keterampilan berkomunikasi, keefektifan proses kelompok. Saling ketergantungan positif yang artinya setiap peserta didik merasa bergantung secara positif dan terikat dengan anggota kelompoknya dengan tanggung jawab menguasai materi, memastikan seluruh anggota kelompok dapat menguasai materi. Interaksi langsung antar peserta didik dengan adanya komunikasi yang baik maka akan berdampak pada hasil belajar yang baik. Pertanggungjawaban individu yang berarti setiap anggota kelompok dapat menyumbang, membantu, dan mendukung satu sama lain. Selain itu harus bertanggung jawab untuk mempelajari materi. Keterampilan berkolaborasi juga sangat penting dalam pembelajaran. Peserta didik dituntut untuk mempunyai keterampilan kolaborasi, sehingga dalam kelompok tercipta interaksi yang baik untuk saling belajar. Sedangkan, keefektifan proses kelompok berarti peserta didik memproses keefektifan kelompok dengan cara mengevaluasi belajar kelompok.

Selain model pembelajaran, proses pembelajaran juga diimbangi dengan metode pembelajaran. Metode pembelajaran yang sesuai dengan model collaborative learning yaitu metode pembelajaran problem solving. Masalah sebagai dasar dalam metode pembelajaran problem solving. Masalah merupakan keadaan atau kesenjangan antara harapan dan kenyataan (Setyosari, 2015:94). Ketika peserta didik menghadapi suatu masalah dan mereka dapat menemukan cara untuk mengatasi masalah, maka peserta didik tersebut dikatakan dapat menyelesaikan masalah atau juga disebut sudah mendapatkan pemecahan masalah. Pemecahan masalah (problem solving) merupakan proses penerimaan masalah sebagai tantangan untuk menyelesaikan masalah (Yuwono, 2016:147). Ketika peserta didik dihadapkan suatu masalah, maka peserta didik tersebut harus bisa memecahkan suatu masalah dengan cara mengetahui pengetahuan yang sudah didapat sebelumnya yang berkaitannya dengan masalah tersebut. Hal ini sesuai dengan Krulik dan Rudnik (dalam Hendriana, 2017:44) menjelaskan bahwa problem solving yaitu proses dimana 
peserta didik menggunakan pengetahuan, keterampilan, dan pemahaman yang telah diperoleh untuk menyelesaikan masalah pada situasi yang belum dikenal.

Metode pembelajaran problem solving merupakan metode dalam proses pembelajaran yang melatih peserta didik menghadapi suatu masalah, baik masalah kelompok maupun individu untuk dipecahkan bersama-sama atau sendiri (Hamdani, 2011:84). Metode pembelajaran problem solving juga merupakan metode berpikir dimulai dari mencari data sampai kesimpulan (Syaiful dalam Karmawati, 2015:88). Sehingga, peserta didik yang telah menghadapi suatu masalah maka selanjutnya peserta didik harus bisa memecahkan masalah dan menemukan kesimpulan dari masalah tersebut. Dengan demikian, maka dapat disimpulkan bahwa metode pembelajaran problem solving merupakan metode pembelajaran yang menekankan peserta didik dalam menyelesaikan masalah diawali dari memahami masalah sampai pemberian kesimpulan dari masalah tersebut. Metode pembelajaran problem solving merujuk pada Polya (dalam Yuwono, 2016:149) menyebutkan bahwa terdapat 4 tahapan yaitu understand the problem (memahami masalah), make a plan (membuat rencana pemecahan masalah), carry out our plan (melaksanakan rencana), look back at the completed solution (memeriksa kembali jawaban).

Agar peserta didik aktif dalam proses pembelajaran matematika dan guru mempunyai berbagai variasi model pembelajaran yang akan diterapkan, maka penulis termotivasi untuk membuat sintaks model pembelajaran matematika collaborative problem solving. Model pembelajaran matematika collaborative problem solving merupakan model pembelajaran yang berasal dari kombinasi model collaborative learning dan metode pembelajaran problem solving. Sintaks pada artikel ini difokuskan pada materi sistem persamaan linear tiga variabel (SPLTV).

\section{HASIL DAN PEMBAHASAN}

Arends (dalam Majid, 2016:13) menjelaskan bahwa model pembelajaran mempunyai makna lebih luas daripada pendekatan, strategi, metode atau prosedur.
Sedangkan, menurut Suprihatiningrum (2016:159) model pembelajaran mencakup pendekatan pembelajaran, strategi pembelajaran, metode pembelajaran, dan teknik pembelajaran. Selain itu, terdapat juga taktik pembelajaran, karena pada teknik pembelajaran tidak terlepas dari taktik pembelajaran. oleh karena itu, untuk mengetahui hubungan antara model, pendekatan, strategi, metode, teknik, dan taktik pembelajaran dapat dilihat pada Gambar 1 berikut.

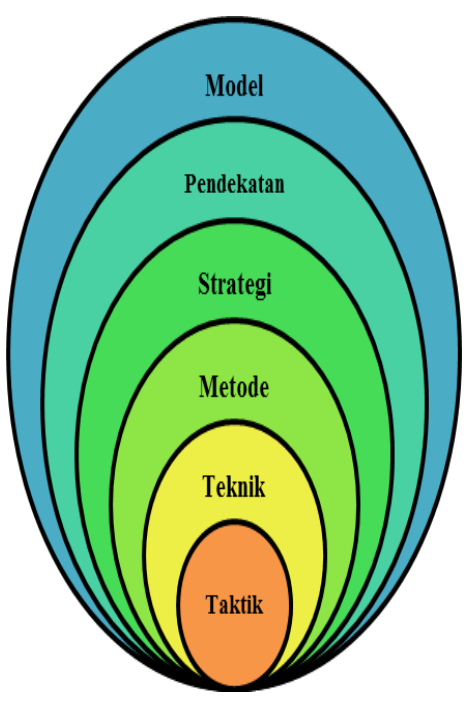

Gambar 1. Hubungan Model, Pendekatan, Strategi, Metode, dan Teknik Pembelajaran

Berikut ini penjelasan terkait Gambar 1 yaitu: 1) model pembelajaran merupakan suatu perencanaan yang menggambarkan sebuah proses pembelajaran dari awal sampai akhir yang digunakan sebagai pedoman guru dalam melaksanaan pembelajaran.; 2) pendekatan pembelajaran merupakan cara yang ditempuh oleh guru dan peserta didik dalam melaksanakan pembelajaran agar materi yang disajikan dapat mencapai tujuan pembelajaran; 3) strategi pembelajaran merupakan rencana tindakan guru untuk mencapai tujuan pembelajaran yang baik; 4) metode pembelajaran merupakan cara yang digunakan oleh guru untuk diimplementasikan ke dalam proses pembelajaran agar mencapai pembelajaran yang optimal; 5) teknik pembelajaran marupakan cara yang dilakukan guru dalam 
menerapkan suatu metode pembelajaran; dan 6) taktik pembelajaran merupakan gaya seorang guru dalam melaksanakan metode dan teknik pembelajaran.

Model pembelajaran matematika collaborative problem solving merupakan model pembelajaran yang melibatkan dua atau lebih peserta didik yang memiliki kontribusi bekerja sama untuk menyelesaikan masalah matematika. Model pembelajaran matematika collaborative problem solving dapat mencakup pendekatan pembelajaran, strategi pembelajaran, metode pembelajaran, teknik pembelajaran, dan taktik pembelajaran. Hal yang mendasari model pembelajaran matematika collaborative problem solving pada materi sistem persamaan linear tiga variabel (SPLTV) dapat dilihat pada Tabel 1 berikut.

Tabel 1. Konsep Model Pembelajaran Matematika Collaborative Problem Solving

\begin{tabular}{cl}
\hline Aspek & \multicolumn{1}{c}{ Penggunaan Model } \\
& Collaborative problem solving \\
\hline \multirow{4}{*}{ Pendekatan } & Pendekatan yang berpusat pada \\
peserta didik (student-centered \\
approaches). Pendekatan student \\
centered berarti peserta didik \\
dituntut untuk menyelesaikan \\
masalah kontekstual tentang Sistem \\
Persamaan Linear Tiga Variabel \\
(SPLTV) yang diberikan oleh guru \\
dengan cara mengingatkan kembali \\
terkait materi Sistem Persamaan \\
Linear Dua Variabel (SPLDV) dan \\
mencari informasi perbedaan dan \\
persamaan antar SPLDV dan \\
SPLTV Namun, guru tetap \\
berperan sebagai motivator, \\
pembimbing, dan fasilitator.
\end{tabular}

\begin{tabular}{cc}
\hline & Penggunaan Model \\
Aspek & Pembelajaran Matematika \\
& Collaborative problem solving
\end{tabular}

memiliki kesulitan dalam memecahakan masalah kontekstual tentang SPLTV, maka guru akan membimbing peserta didik dalam menemukan solusi dari permasalahan kontektual tersebut. Sedangkan dalam penyajian dan cara mengolahnya, model pembelajaraan ini menggunakan strategi pembelajaran deduktif. Dalam hal ini, peserta didik harus mempelajari konsep materi SPLTV terlebih dahulu. Jika peserta didik paham tentang konsep materi SPLTV, maka peserta didik dapat memecahkan suatu masalah kontekstual tentang SPLTV. Metode pembelajaran problem solving yang bertujuan untuk meningkatkan keaktifan dan kemampuan peserta didik dalam memecahkan masalah kontekstual tentang Sistem Persamaan Linear Tiga Variabel (SPLTV) yang telah diberikan oleh guru. Metode pembelajaran problem solving merujuk pada tahapan Polya, agar diharapkan peserta didik lebih sistematis dalam memecahkan suatu masalah kontekstual tentang SPLTV.

Teknik pembelajaran dalam model pembelajaran ini yaitu guru membagikan kelompok berdasarkan latar belakang dan kemampuan peserta didik yang bervariasi. Sehingga, peserta didik yang berkemampuan rendah akan meningkatkan kemampuan mereka dalam memecahkan suatu masalah kontekstual tentang Sistem Persamaan Linear Tiga Variabel (SPLTV) karena dalam tiap kelompok terjadi saling melengkapi antar peserta didik yang satu dengan yang lain ketika memecahkan suatu masalah kontekstual tentang SPLTV. Taktik Taktik pembelajaran dalam mode 


\begin{tabular}{|c|c|}
\hline Aspek & $\begin{array}{c}\text { Penggunaan Model } \\
\text { Pembelajaran Matematika } \\
\text { Collaborative problem solving }\end{array}$ \\
\hline pembelajaran & $\begin{array}{l}\text { pembelajaran ini yaitu guru } \\
\text { membagikan LKPD (Lembar Kerja } \\
\text { Peserta Didik) yang memuat } \\
\text { berbagai masalah kontektual } \\
\text { tentang Sistem Persamaan Linear } \\
\text { Tiga Variabel (SPLTV) kepada tiap } \\
\text { kelompok dan selanjutnya tiap } \\
\text { kelompok harus mengerjakan } \\
\text { LKPD tersebut. }\end{array}$ \\
\hline
\end{tabular}

Dari uraian di atas, diperoleh bahwa model pembelajaran matematika collaborative problem solving dapat mencakup sebagai berikut: (1) pendekatan student centered; (2) strategi discovery learning dan strategi pembelajaran deduktif; (3) metode pembelajaran problem solving; (4) teknik belajar kelompok; dan (5) taktik pengerjaan LKPD. Sehingga, konsep model pembelajaran matematika collaborative problem solving diperoleh hubungan yang dapat dilihat pada Gambar 2 berikut.

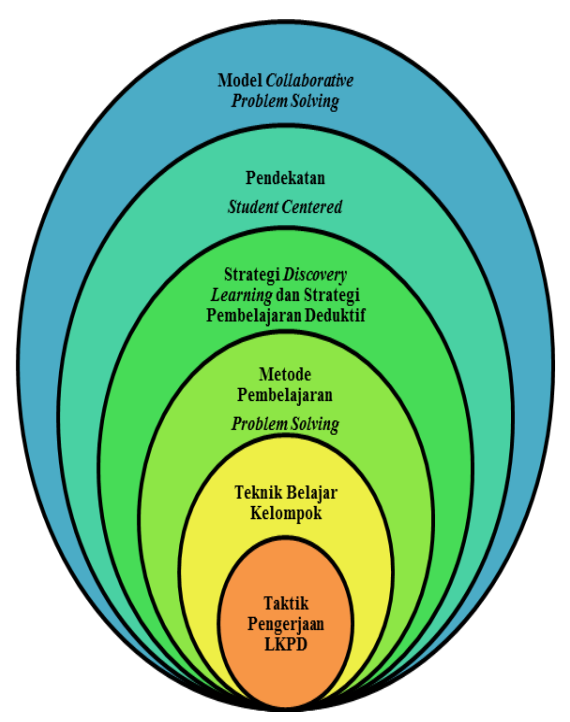

Gambar 2. Model Pembelajaran Matematika Collaborative Problem Solving

Selain hal-hal yang mencakup model pembelajaran matematika collaborative problem solving, salah satu hal terpenting dalam model pembelajaran ini yaitu tahapan kegiatan pembelajaran atau sintaks (Suprihatiningrum, 2016:44). Sintaks model pembelajaran harus dilakukan oleh guru dan peserta didik selama proses pembelajaran agar pembelajaran sesuai dengan tujuan yang diinginkan. Sintaks model pembelajaran matematika collaborative problem solving sebagai berikut.

\section{1) Engagement (Pengelompokan)}

Pada tahapan pertama, guru membagikan kelompok berdasarkan kemampuan yang berbeda-beda dengan cara melihat hasil pretest peserta didik pada materi Sistem Persamaan Linear Tiga Variabel (SPLTV).

\section{2) Exploration (Pemberian Masalah)}

Pada tahapan kedua, guru memberikan masalah kontekstual tentang Sistem Persamaan Linear Tiga Variabel (SPLTV) kepada tiap kelompok. Semua anggota kelompok memahami permasalahan kontekstual tersebut untuk membedakan antara apa yang diketahui dan apa yang ditanyakan. Setelah itu, peserta didik dalam tiap kelompok terdapat peran atau tugas masing-masing yang dikoordinasi oleh ketua kelompok untuk membuat rencana pemecahan masalah kontekstual tentang Sistem Persamaan Linear Tiga Variabel (SPLTV).

\section{3) Transformation (Diskusi Kolaboratif)}

Pada tahapan ketiga, peserta didik dalam tiap kelompok saling tukar pendapat/ide dalam diskusi untuk melaksanakan rencana pemecahan masalah kontekstual tentang Sistem Persamaan Linear Tiga Variabel (SPLTV) yang telah disusun. Dalam melaksanakan suatu rencana pemecahan masalah kontekstual tersebut harus dibutuhkan latihan dan konsentrasi yang baik. Ketika gagal dalam melaksanakan rencana pemecahan masalah kontekstual SPLTV, maka harus dilakukan revisi dan mengubah rencana pemecahan masalah kontekstual tersebut sehingga diperoleh suatu jawaban.

\section{4) Solution (Pengecekan Hasil Diskusi Kelompok)}

Pada tahapan keempat, peserta didik dalam tiap kelompok yang memperoleh jawaban dari masalah kontekstual tentang Sistem Persamaan Linear Tiga Variabel (SPLTV), selanjutnya peserta didik harus memeriksa kembali jawaban tersebut. Hal ini 
bertujuan untuk mengetahui kebenaran solusi dari masalah kontekstual tersebut. Sehingga, tiap kelompok dapat memperoleh suatu kesimpulan dari masalah kontekstual SPLTV.

\section{5) Presentation (Presentasi Hasil Diskusi Kelompok)}

Pada tahapan kelima, kelompok mempresentasikan hasil diskusi terkait masalah kontekstual tentang Sistem Persamaan Linear Tiga Variabel (SPLTV). Jika kelompok melakukan presentasi, maka kelompok yang lain mengamati, mencermati, dan menanggapi hasil diskusi kelompok yang presentasi.

\section{6) Reflection (Umpan Balik dan Penilaian)}

Pada tahapan keenam, guru membimbing peserta didik dalam menyimpulkan materi Sistem Persamaan Linear Tiga Variabel (SPLTV) setelah proses tanya jawab diskusi kelompok.

Adapun sintaks model pembelajaran matematika collaborative problem solving yang dapat diterapkan oleh guru dan peserta didik dalam pelaksanaan pembelajaran pada materi sistem persamaan linear tiga variabel (SPLTV) dapat dilihat pada Tabel 2 berikut.

Tabel 2. Sintaks Model Pembelajaran Matematika Collaborative Problem Solving

\begin{tabular}{|c|c|c|c|c|}
\hline No & Tahapan & Aktivitas Guru & 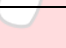 & Aktivitas Peserta didik \\
\hline 1 & $\begin{array}{l}\text { Engagement } \\
\text { (pengelompokkan) }\end{array}$ & $\begin{array}{l}\text { Guru membagikan } \\
\text { kelompok berdasarkan } \\
\text { kemampuan berbeda- } \\
\text { beda yang diperoleh } \\
\text { melalui hasil pretest } \\
\text { pada materi SPLTV. }\end{array}$ & & $\begin{array}{l}\text { Peserta didik berkumpul sesuai pembagian } \\
\text { kelompok yang ditentukan oleh guru. }\end{array}$ \\
\hline 2 & $\begin{array}{l}\text { Exploration } \\
\text { (pemberian masalah) }\end{array}$ & $\begin{array}{l}\text { Guru memberikan } \\
\text { masalah kontekstual } \\
\text { tentang SPLTV. } \\
\text { - } \text { Guru bertindak } \\
\text { sebagai motivator dan } \\
\text { pembimbing. }\end{array}$ & & $\begin{array}{l}\text { Peserta didik dalam tiap kelompok mencoba } \\
\text { memahami masalah kontekstual tentang SPLTV } \\
\text { yang diberikan oleh guru, seperti apa yang } \\
\text { diketahui dan apa yang ditanyakan. } \\
\text { Peserta didik dalam tiap kelompok terdapat peran } \\
\text { atau tugas masing-masing yang dikoordinasi oleh } \\
\text { ketua kelompok untuk membuat rencana } \\
\text { pemecahan masalah kontekstual tentang SPLTV. }\end{array}$ \\
\hline 3 & $\begin{array}{l}\text { Transformation } \\
\text { (diskusi kolaboratif) }\end{array}$ & $\begin{array}{l}\text { Guru bertindak } \\
\text { sebagai pembimbing. }\end{array}$ & $\sim$ & $\begin{array}{l}\text { Peserta didik dalam tiap kelompok melaksanakan } \\
\text { rencana pemecahan masalah kontekstual tentang } \\
\text { SPLTV yang telah disusun. }\end{array}$ \\
\hline 4 & $\begin{array}{l}\text { Solution } \\
\text { (pengecekan hasil } \\
\text { diskusi kelompok) }\end{array}$ & $\begin{array}{l}\text { - Guru bertindak } \\
\text { sebagai pembimbing. }\end{array}$ & & $\begin{array}{l}\text { Peserta didik dalam tiap kelompok memeriksa } \\
\text { kembali tiap langkah rencana pemecahan masalah } \\
\text { kontekstual tentang SPLTV. }\end{array}$ \\
\hline 5 & $\begin{array}{l}\text { Presentation } \\
\text { (presentasi hasil diskusi } \\
\text { kelompok) }\end{array}$ & $\begin{array}{l}\text { - Guru bertindak } \\
\text { sebagai pelatih. }\end{array}$ & & $\begin{array}{l}\text { Tiap kelompok mempresentasikan hasil diskusi } \\
\text { terkait masalah kontekstual tentang SPLTV. } \\
\text { Antar kelompok saling tanya jawab terkait hasil } \\
\text { presentasi. }\end{array}$ \\
\hline 6 & $\begin{array}{l}\text { Reflection } \\
\text { (umpan balik } \\
\text { penilaian) }\end{array}$ & $\begin{array}{l}\text { - } \text { Guru bertindak } \\
\text { sebagai fasilitator. }\end{array}$ & & $\begin{array}{l}\text { Peserta didik bersama dengan guru menyimpulkan } \\
\text { materi SPLTV. }\end{array}$ \\
\hline
\end{tabular}

\section{SIMPULAN}

Berdasarkan uraian di atas, dapat disimpulkan bahwa model pembelajaran matematika collaborative problem solving merupakan model pembelajaran yang melibatkan dua atau lebih peserta didik yang memiliki kontribusi bekerja sama untuk menyelesaikan masalah matematika.
Model pembelajaran ini mencakup hal: (1) pendekatan student centered; (2) strategi discovery learning dan strategi pembelajaran deduktif; (3) metode pembelajaran problem solving; (4) teknik belajar kelompok; dan (5) taktik pengerjaan LKPD. Setelah terbentuk model pembelajaran matematika collaborative problem solving, 
selanjutnya terdapat sintaks/tahapan model pembelajaran matematika collaborative problem solving sebagai berikut: (1) engagement (pengelompokkan); exploration (pemberian masalah); (3) transformation (diskusi kolaboratif); (4) solution (pengecekan hasil diskusi kelompok); (5) presentation (presentasi hasil

\section{DAFTAR PUSTAKA}

Abidin, Zainal., dkk. (2016). Pengembangan Model Pembelajaran Matematika Berbasis Portofolio (PMBP) pada Siswa Sekolah Menengah Pertama. Jurnal Pendidikan Matematika (JPM), Vol. 2, No. 1, Februari 2016.

Barkley, Elizabert E. (2005). Collaborative Learning Techniques. Terjemahan oleh Narulita Yusron. 2014. Bandung: Nusa Media.

Damayanti, Ni Komang Ari. (2017). Peningkatan Kemampuan Literasi Matematika Siswa melalui Penerapan Collaborative Learning Model. Jurnal Matematika, Sains, dan Pembelajarannya (Wahana Matematika dan Sains), Vol. 11, No. 1, April 2017.

Hamdani. (2011). Strategi Belajar Mengajar. Bandung: Pustaka Setia.

Hendriana, Heris., dkk. (2017). Hard Skills dan Soft Skills Matematik Siswa. Bandung: PT. Refika Aditama.

Husain, Rusmin. (2012). Pengembangan Model Pembelajaran Kolaboratif dalam Meningkatkan Hasil Belajar Warga Belajar Paket C. Disertasi tidak diterbitkan. Bandung: Program Pascasarjana Universitas Pendidikan Indonesia.

Joyce, Bruce., dkk. (2009). Models of Teaching. Terjemahan oleh Ahmad Fawaid dan Ateilla Mirzani. 2011. Yogyakarta: Pustaka Pelajar.

Karmawati. (2015). Penerapan Metode Pembelajaran Problem Solving dalam Meningkatkan Hasil Belajar Statistika Mahasiswa pada Fakultas diskusi kelompok); dan (6) reflection (umpan balik dan penilaian). Sintaks model pembelajaran matematika collaborative problem solving dapat diimplementasikan kepada peserta didik pada materi Sistem Persamaan Linear Tiga Variabel (SPLTV) khususnya menyelesaikan masalah konstektual melalui SPLTV.

Tarbiyah dan Ilmu Keguruan IAIN Palu. Jurnal Penelitian Ilmiah (ISTIQRA), Vol. 3, No. 1, Juni 2015.

Khoiriyah, Annisatul. (2016). Pembelajaran Kolaboratif pada Matematika untuk Membentuk Karakter Generasi. Jurnal Matematika dan Pendidikan Matematika, Vol. 1, No. 1, Maret 2016.

Majid, Abdul. (2016). Strategi Pembelajaran. Bandung:

PT. Remaja Rosdakarya.

Setyosari, Punaji. (2015). Metode Penelitian Pendidikan dan Pengembangan. Jakarta: Kencana.

Siregar, Eveline., \& Nara, Hartini. (2014). Teori Belajar dan Pembelajaran. Bogor: Ghalia Indonesia.

Sunismi., \& Fathani, Abdul Halim. (2017). Pengembangan Model Collaborative Learning Matematika Berbasis Media Blog Matakuliah Kalkulus II. Makalah disajikan dalam rangka Seminar Nasional Matematika dan Aplikasinya, Universitas Airlangga Surabaya, 21 Oktober 2017. Suprihatiningrum, Jamil. (2016). Strategi Pembelajaran Teori dan Aplikasi. Yogyakarta: Ar-Ruzz Media. Thobroni, Muhammad., \& Mustofa, Arif. (2013). Belajar \& Pembelajaran Teori Pengembangan Wacana dan Praktik Pembelajaran dalam Membangun Nasional. Yogyakarta: Ar-Ruzz Media.

Trianto. (2011). Model Pembelajaran Terpadu. Jakarta: Bumi Aksara.

Yuwono, Aries. (2016). Problem Solving dalam Pembelajaran Matematika. Jurnal Pendidikan Matematika (UNION), Vol. 4, No. 1, Maret 2016. 